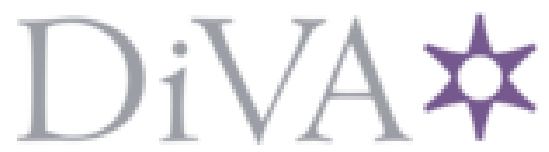

http://www.diva-portal.org

This is the published version of a paper published in International Journal of Information and Communication Technologies in Education.

Citation for the original published paper (version of record):

Mozelius, P. (2017)

Problems Affecting Successful Implementation of Blended Learning in Higher Education: - the Teacher Perspective.

International Journal of Information and Communication Technologies in Education, 6(1): 4-13 https://doi.org/DOI: 10.1515/ijicte - 2017 - 0001

Access to the published version may require subscription.

N.B. When citing this work, cite the original published paper.

Permanent link to this version:

http://urn.kb.se/resolve?urn=urn:nbn:se:miun:diva-30667 


\title{
Problems AfFecting SucCessful IMPLEMENTATION OF BLENDED LEARNING IN HIGHER EDUCATION - THE TeACHER PERSPeCtive
}

\author{
Peter Mozelius ${ }^{1}$, Claes Rydell ${ }^{2}$
}

\author{
${ }^{1}$ Department of Computer and Systems Sciences, Mid Sweden University, Östersund, Sweden \\ \{peter.mozelius@miun.se\}
}

${ }^{2}$ Department of Computer and Systems Sciences, Stockholm University, Stockholm, Sweden \{clry3018@student.su.se\}

\begin{abstract}
An increased use of blended learning environments in higher education has been an emerging trend in the 21st century. Sometimes the definition of blended learning has been so broad that it makes it hard to find any learning environment in higher education that would not be included. Many research studies have been reporting the pros and cons of blended learning from the university perspective and the learner perspective. There are less studies on the teacher view of blended learning environments. This study had the aim to explore, analyse and discuss teachers' perceived problems and barriers to a successful implementation of blended learning at university level.
\end{abstract}

The used research strategy was a qualitative cross-sectional study where data has been collected with semistructured interviews. Six teachers that all are subject matter experts and instructional designers for courses on computer science were interviewed. In a computer assisted thematic analysis found codes and keywords was grouped together to create themes.

Four themes or problematic areas were found, and that they combined could give an explanation to what teachers experience as problems when implementing blended learning environments. First theme is documentation and support, where teachers find the scarcity of documentation in their virtual learning environment a problem for implementing extension modules. Second theme is introduction and training, where teachers find it problematic that they rarely get a proper introduction or further training on the use of tools and modules. Third theme is the time aspect, teachers suffer from the lack of time to implement blended learning thoroughly in their courses. Last found theme is didactics, where teachers do not feel that they have the required knowledge or skills to apply the appropriate instructional design for blended learning environments.

\section{KEYWORDS}

Blended learning, Virtual learning environment, Technology enhanced learning, Higher education, E-learning

\section{INTRODUCTION}

Blended learning in higher education is a widely discussed phenomenon that rapidly has increased in the 21 st century and as pointed out by Garrison \& Kanuka (2004) the adoption of blended learning approaches in higher education is an inevitable fact. From being an experimental concept in distance education courses, blended learning environments are today part of mainstream education. In a broader definition blended 
learning could be described as the mix of traditional face-to-face learning and the use of technology enhanced learning tools and techniques in virtual online environments (Watson, 2008).

Technology enhanced learning is in this study seen as information and communication technology (ICT) used in educational contexts with the aim to enhance students learning and interaction. Blended learning is mainly implemented in a virtual learning environments (VLE) where the VLE in this paper is an adapted variation of the Moodle platform. The prime objective in the implementation of blended learning environments should be to create a richer learning process with motivated students by combining face-toface sessions with according online activities (Bourne \& Seaman, 2005) with a multimodal overload that could satisfy the needs for various study techniques and learning styles (Picciano, 2009).

The design of blended learning should always be based on the learning context, the specific subject and its actual learning objectives (Neumeier, 2005). Furthermore, it has been pointed out as an important factor to include student interaction in blended learning environments (Garner \& Rouser, 2016), but not all blended learning courses need to require students to do group work or rely entirely on reflective activities (Picciano, 2009). Despite the ambition to combine the best parts of the two worlds the blend sometimes ends up with a mix of the worst features of the two (Bonk \& Graham, 2012).

As pointed out by Chen and Yao (2016), a tendency in previous studies on blended learning has been to identify and discuss factors with a prime focus on technology. On the other hand there are several studies promoting the idea of focusing on pedagogy and learning objectives instead (Hoffman, 2006; Garrison \& Vaughan, 2008; Alammary et al., 2014; McGee \& Reis, 2012; Shand, Glassett-Farrelly \& Costa, 2016). There are less studies on university teacher's view of the implementation of blended learning.

\section{Problem}

The described potential of blended learning have in many cases not been successfully implemented. According to a Swedish case study carried out by Garrote (2012), teachers use VLEs mainly to distribute documents, send messages and for course administration and not to enable interaction and collaboration. Previous research also indicates that teachers' perception of an online tools' ease of use is directly connected to the teachers' sensation of lack of time and lack of support to implement it (Lonn \& Teasley, 2009).

\section{Research question}

The main question to answer in this study is: Which are university teachers' perceived problems and barriers to a successful implementation of blended learning in courses on computer science?

\section{EXTENDED BACKGROUND}

As highlighted in a study by Garrison \& Kanuka (2004) the implementation of blended learning in higher education is inevitable and a global shift involving most regions in the world (Raphael \& Mtebe, 2016; Mozelius, 2014; Fleming, Becker \& Newton, 2017). With the constant hype of blended learning in the 21st century hype in the 21 st century the definition has sometimes been so wide that it makes it hard to find any learning system in higher education that is not included (Graham, 2006). The straightforward onedimension broadly definition could be as described by Watson (2008), "The convergence of online and face-to-face Education". A for this study more interesting definition is the one depicted in the multimodal conceptual model by Picciano (2009) that is depicted below. 


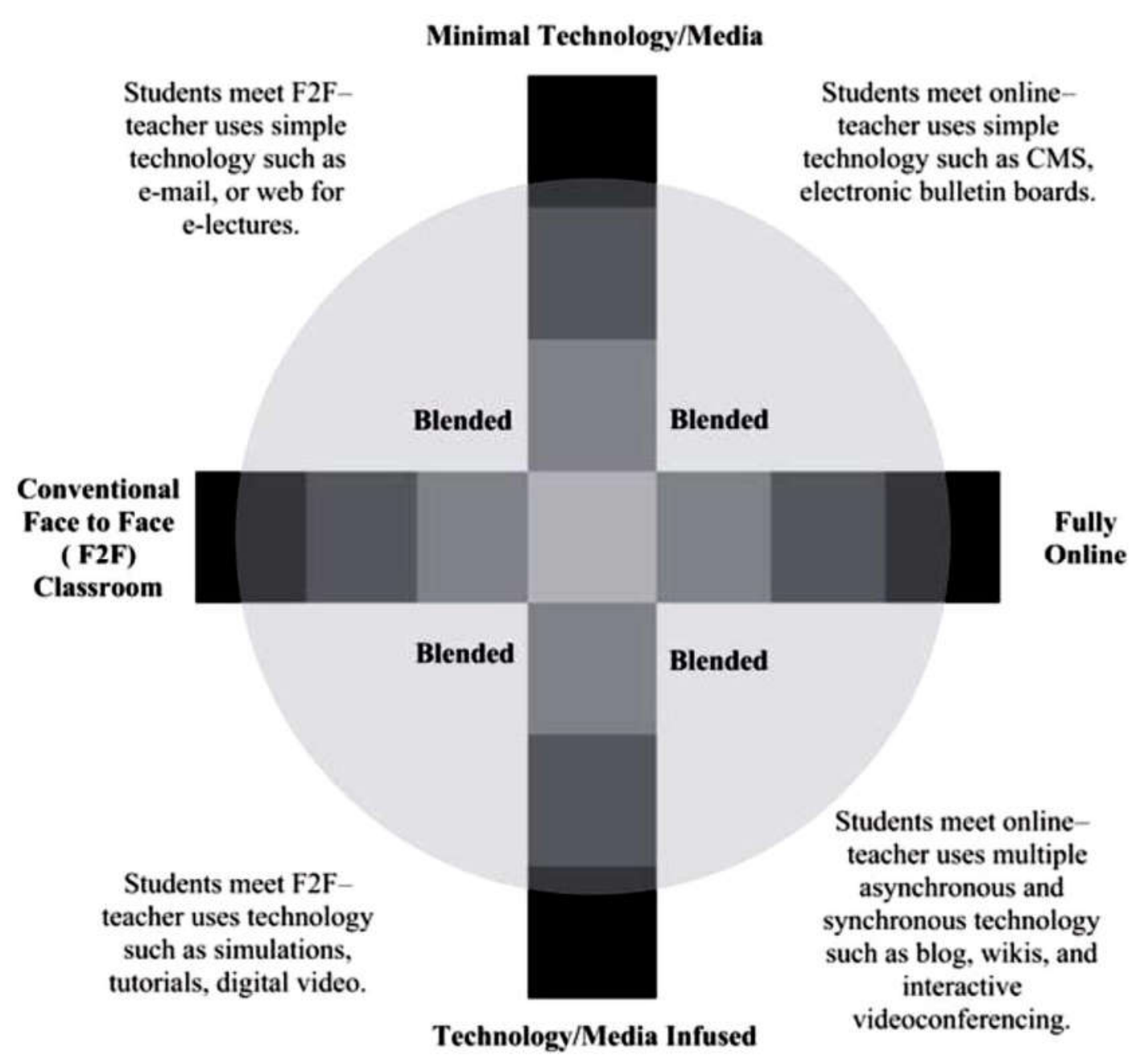

Figure 1 Picciano's multimodal conceptual blended learning model

One of Picciano's multimodal concepts is the idea of a high degree of media infusion has the potential to meet different needs and different learning styles in today's heterogeneous student groups. Other research studies indicate that students tend to be more socially engaged if the virtual learning environments involves dynamic and interactive media formats. Techniques to use could be discussions fora, facilitating interaction and resources in forms of graphics and audio or video files. (Kim, Kwon \& Cho, 2011) Another promising interactive blend is to use the motivational effect of game-based learning which also is possible to implement as collaborative learning with student interaction (Babu et al., 2016).

\section{Trends or hypes}

Like most other phenomena blended learning has its trend and hypes. One trend that makes sense is when blended learning, that originally was started to enhance traditional learning, today is used to balance pure online distance learning with face-to-face activities (Garner \& Rouser, 2016). Two other hyped trends today are the Massive Open Online Courses (MOOCs) and the well-discussed concept of 'The Flipped Classroom'.

MOOCs that initially, when the concept was launched, were praised have later been criticised for the focus on reducing costs for mass education (Waldrop, 2014), and also for high drop-out rates and poor learning outcomes (Holland, 2016). A more promising concept seem to the idea of a flipped classroom (Herreid, \& Schiller, 2013; Thai, De Wever, \& Valcke, 2017) involving students' self-preparation before plenum activities. The concept shows many of the problems earlier seen in instructional methods that depend on 
students preparing outside of ordinary class (Herreid, \& Schiller, 2013), but the majority of blended learning researchers seem to view the flipped classroom as a strategy worth implementing (Slomanson, 2014).

\section{Blended learning perspectives}

Like in many fields successful outcomes can be achieved with multi-stakeholder approach with benefits for all involved stakeholders. This study is based on the teachers' perspective, but there are at least two other important perspectives.

\section{The University perspective}

There exist multiple reasons for universities to involve and invest in blended learning. Firstly, the potential for pedagogical variety and technology enhanced didactics combined with the increased access to knowledge, anytime and anywhere. Secondly, important reasons like cost effectiveness and the ease of revision must be mentioned as well (Graham, 2006). Finally, another reason is to open up for lifelong learning and that older students tend to enjoy the flexibility of asynchronous online activities (So \& Brush, 2008).

Furthermore, one of the most obvious advantages of technology enhanced learning is that courses' enrolment, administration, delivery and assessment all could be automated and put online. A fact that practically removes the upper limits of student enrolment in online education (Holland, 2016). To be compared with the student perspective where increased social presence and learner satisfaction are important (Garner \& Rouser, 2016).

\section{The Learner perspective}

Blended learning education must live up to the same standards as traditional educational settings, otherwise it is not an interesting alternative for most learners. Updated high quality course content is always essential for the learning outcomes (Lin \& Wang, 2012) and the same goes for the quality of the virtual learning environment (Lin \& Wang, 2012; Al-Busaidi, 2012).

Furthermore blended learning must not only be about the distribution of course content or learning activities (Graham, 2006), there should also be a concern about including students' social and emotional needs (Picciano, 2009). Finally, the recommendation is to keep a learner centred design (Watson, 2008), and to care about learner needs such as discussions, collaboration and emotional support (So \& Brush, 2008).

\section{METHODOLOGY, DATA COLLECTION AND ANALYSIS}

This study has been conducted as a qualitative cross-sectional study with data collected from a representative subset of university teachers at a specific point in time. A pointed out problem with crosssectional studies is that they are snapshots where the inquiry may provide differing results if another timeframe had been chosen (Levin, 2006). An advantage with cross sectional studies are useful at identifying associations that later can be followed-up and more thoroughly studied (Mann, 2003). The vast majority of cross-sectional studies have a quantitative design with a use of structured interview and questionnaire research, while studies on the qualitative side tend to use semi-structured interview (Bryman, 2006).

Given the goals and logic of the qualitative approach, purposive sampling is often the employed strategy to enhance understandings of selected individuals or groups' experiences. To accomplish the research goals, a purposive sampling strategy should build on a selection of individuals or groups that provide the greatest insight into the research question (Devers, \& Frankel, 2000). For this study six university teachers that all are subject matter experts and instructional designers for courses on computer science were interviewed during 2016. They all work at a department for computer and systems sciences and data was collected by recording semi-structured interviews.

Recorded interviews were transcribed and analysed thematically. The first part of the analysis was carried out with help of the computer-assisted qualitative data analysis software (CAQDAS) tool NVivo. A CAQDAS tool facilitates the identification of keywords and patterns in unstructured qualitative data (QSR 
International, 2016). The output from the CAQDAS tool was also further analysed manually before the presentation and discussion in the following chapter 4.

\section{$4 \quad$ FINDINGS AND DISCUSSIONS}

Interviewees' earlier experience and usage of blended learning environments show large variations which can be illustrated by the answers to the following three questions:

Question 1: What is your earlier experience of blended learning?

\begin{tabular}{|l|l|}
\hline Informant 1 & "Not much" \\
\hline Informant 2 & "I have used blended learning to various degrees in my courses" \\
\hline Informant 3 & "I have used it, but not consciously or with purpose" \\
\hline Informant 4 & "I use it in all my courses" \\
\hline Informant 5 & "Blended learning is something that I always use in my courses" \\
\hline Informant 6 & "Yes, I've used it a bit in my courses" \\
\hline
\end{tabular}

Question 2: How do you use blended learning in your courses?

\begin{tabular}{|l|l|}
\hline Informant 1 & $\begin{array}{l}\text { "Not much, I've tried to use parts of the 'Flipped classroom' concept such } \\
\text { as the idea of providing students recorded material before lectures. But I } \\
\text { prefer to not record my lectures, I think it gives a worse outcome. We also } \\
\text { use online submissions of assignments with feedback during the course" }\end{array}$ \\
\hline Informant 2 & $\begin{array}{l}\text { "With variations in the various courses. Mostly I use the VLE for course } \\
\text { structure and time framing, but also video recorded tutorials" }\end{array}$ \\
\hline Informant 3 & "I record my lectures and put all course content online" \\
\hline Informant 4 & $\begin{array}{l}\text { "I have synchronous chat and/or asynchronous fora. Fora in the VLE are } \\
\text { also used for supervision and facilitating sessions of student groups. Every } \\
\text { group in a separate thread that all groups have access to" }\end{array}$ \\
\hline Informant 5 & $\begin{array}{l}\text { "All the course content including recorded lectures is uploaded online. The } \\
\text { major part of the teacher - student interaction is conducted in online fora." }\end{array}$ \\
\hline Informant 6 & $\begin{array}{l}\text { "Adapted ad hoc to the course conditions. Lectures / workshops are } \\
\text { followed up online like student postings in VLE fora. Also online surveys } \\
\text { that that later are discussed on lectures. Mainly a primitive use" }\end{array}$ \\
\hline
\end{tabular}

Question 3: What is your idea of how blended learning should be implemented?

\begin{tabular}{|l|l|}
\hline Informant 1 & $\begin{array}{l}\text { "My idea is to increase not only the student-student interaction but also the } \\
\text { student-teacher interaction. That's when the most exciting things turn up, } \\
\text { and without this interaction the course could be in distance mode only." } \\
\text { "Try to find tools that supports this with high 'communication bandwidth', } \\
\text { where video chats and F2F have the highest bandwidths'. }\end{array}$ \\
\hline Informant 2 & $\begin{array}{l}\text { "You must always design based on the given resources. My courses are not } \\
\text { meant to have a blended learning design. Lectures are recorded during F2F } \\
\text { sessions which works ok. But if you should learn from the video only the } \\
\text { demands on the recording are much higher." "The question is what is } \\
\text { possible to have in distance mode and must be in F2F sessions. This } \\
\text { depends also on the number of students" }\end{array}$ \\
\hline Informant 3 & $\begin{array}{l}\text { "No idea, I think you should learn more Pedagogy and not only the } \\
\text { technical side." "It's also very subject matter specific." }\end{array}$ \\
\hline Informant 4 & $\begin{array}{l}\text { "My personal opinion is to keep the F2F sessions where you can read the } \\
\text { students' faces and understand when they don't understand or when they } \\
\text { are bored." "I think a 50-50 mix works and to use the F2F feedback }\end{array}$ \\
\hline
\end{tabular}




\begin{tabular}{|l|l|}
\hline & $\begin{array}{l}\text { channel that you miss online. Some teachers feel comfortable when they } \\
\text { skip all lectures, I only take away half." There's no eye contact online" } \\
\text { "Recorded lectures, and teacher led facilitation sessions online to answer to } \\
\text { students' questions." }\end{array}$ \\
\hline Informant 5
\end{tabular}

After the further analysis of all answers to all interview questions, found patterns and subthemes were grouped into four main themes:
1. Documentation and Support
2. Introduction and Training
3. The Time Aspect
4. Didactics and instructional design

\section{Documentation and Support}

The first theme is Documentation and Support, or rather the lack of documentation and support. Several informants brought up the problem that if the documentation for a certain VLE module is insufficient it gives you an insecure feeling in the implantation. "It feels hard to get an overview of what's available. If there is someone who has used this module earlier you can ask, otherwise it's hard to find out how new nodules work." (Informant 1 ).

If situations where there is no colleague that can explain or help out there is a risk that the module will not be installed, and sometimes modules are interdependable. "There is one thing that would need support, a grading system where the reports should be shared among teachers. We have used another module as a workaround, but that causes another problem." (Informant 4). Another teacher said that: "My wish is to get a proper introduction to the existing tools and modules. Like it is now you're supposed to know this. It's a lot of trial and error and if you're lucky you find a tutorial on the net." (Informant 6).

It has earlier been highlighted in the study by Christie \& Garotte (2011) that the lack of support is a barrier to reach the full potential of the blended learning environment. Their idea of a support model is a combination of contact persons and documentation that explains both the implementation process and the advantages of using tools and extension modules. This is also aligned to the next found theme indicating the importance of introduction and training.

\section{Introduction and Training}

Another way to make teachers more familiar with tools and techniques would be to provide some training that introduces new technology. One teacher mention that: "There is a reason that I haven't implemented all the technology support I want, I haven't got any introduction on how to use them". A colleague points out that: "It's mainly stuff that I use frequently that I implement since I then know how they work" (Informant 2).

Several informants brought up the lack of training and introduction to things that they are expected to use. "What can be stressful is when you don't understand a tool properly, this can have negative consequences later in the course and generate extra workload" (Informant 6). This also brings us over to the next theme, the time aspect where one informant claims that:

"There are certainly many useful modules, but it's hard for me to estimate how long it takes to get a grip. And for that reason I sometimes skip the implementation." And the same informant adds that: "The lack of information combined with the difficult time estimation keep me away from embracing new technology".

Blended learning environments have been described as the opportunity to combine the best from traditional classroom education with technology enhanced learning (Bourne \& Seaman, 2005), but without adequate introduction and training the implementation risks to be poor. 


\section{The Time Aspect}

Another important factor that was found in the analysis is the time aspect. Even in cases when teachers have a strong motivation to implement new tools and techniques, the start-up time learning how to implement the actual tool or technique can be too long and a critical factor. One teacher said that "When I can't estimate the time it takes to get familiar with a tool, I hesitate" (Informant 6) and another interviewee told that "Even if I've got support with some training, the actual time for implementation is so long so it is never done" (Informant 1).

It is obvious that the time aspect matters but there are sometimes a combination of lack of time and motivation: "I haven't had the time, neither the motivation to get familiar with all parts". If the personal effort is very time consuming or if there is too few hours given for self-studies is hard to tell from the answers. However findings support the results in the study by Lonn and Teasley (2009) indicating teachers' perceived lack of time and lack of support is aligned to the implementation and use of a tool in a course. This can also be aligned to the previous theme 'Introduction and Training'.

\section{Didactics and instructional design}

A frequently cited reason for implementing blended learning is the possibility for more effective didactical practices, but the implementation has not always been successful in blended learning environments (Graham, 2008). A study by Garrison and Vaughan (2007) points out that blended learning should not only be an administrative support opening up for a higher intake, but also be a part of the instructional design. But according to the interviewed teachers this is not always easy to achieve.

In particular Informant 3 saw this as a problem: “I'm afraid to involve in this since I don't know which formats that suits which types of students. My experience is that most discussions get stuck in technical details, while I feel that it is the pedagogical situation that I can't handle." Furthermore he claims that: "I find it important to learn more about pedagogy and its practical implications" (Informant 3).

The natural follow-up question was to ask how much support and training that are provided by the department or by the university. There exist some courses but according to Informant 3: "We had mandatory courses on computer assisted teaching and learning but unfortunately they were not about what I wanted, pedagogy. They were mostly about meta-perspectives, about the future of universities and about tools for online learning. How pedagogy and instructional design affects the students were not brought up. Here I think we have a knowledge gap".

\section{CONCLUSION}

This study has been conducted at a department of computer and system sciences with a cross-sectional design for a relatively small sample. It is hard to generalise, but the answer to the research question about university teachers' perceived problems and barriers to a successful implementation of blended learning is the four found themes:

1. Documentation and Support: The lack of documentation and support has resulted in that certain tools and VLE modules never have been implemented.

2. Introduction and Training: Teachers' perception were that they have not got the appropriate introduction and training to implement blended learning successfully.

3. The Time Aspect: There existed a perceived time shortage hampering the implementation of blended learning tools and techniques.

4. Didactics and instructional design: Teachers did not feel safe and well-informed when it comes to pedagogy, didactics and instructional design for blended learning environments.

Themes can be compared with the findings in the study by Christie and Garrote (2011) where lack of time and lack of support were reported as barriers to a successful use of VLEs. The absence of training in pedagogy, didactics and instructional design has also been highlighted by Garrison and Vaughan (2008). 
Finally, the recommendation is to address the described teacher problems before experimenting with trendy phenomena such as MOOCs or complex flipped classroom implementations.

\section{FUTURE WORK}

This study had a focus on teachers' perceived problems and barriers to the implementation of blended learning at one institution for computer and systems sciences. Interesting future studies would be to: a) a similar study at another department of computer and systems sciences, b) a similar study at a department in the field of humanities or c) a large scale survey targeting a multitude of departments at various universities. Another fourfold research idea would be to dig deeper with separate studies for each of the found themes.

\section{REFERENCES}

Alammary, A.; Sheard, J. \& Carbone, A. (2014). Blended learning in higher education: Three different design approaches. Australasian Journal of Educational Technology, 30.

Al-busaidi, Kamla Ali; Al-Shihi, Hafedh. (2012). Key factors to instructors' satisfaction of learning management systems in blended learning. Journal of Computing in Higher Education, 24: 18-39.

Babu, Sooraj K., et al. (2016). Collaborative Game Based Learning of Post-Disaster Management: Serious Game on Incident Management Frameworks for Post Disaster Management. In: Technology for Education (T4E), 2016 IEEE Eighth International Conference on. IEEE, p. 80-87.

Bonk, Curtis J.; Graham, Charles R. (2012). The handbook of blended learning: Global perspectives, local designs. John Wiley \& Sons.

Bourne, K. \& Seamna, J. (2005). Sloan-C special survey report: A look at blended learning. Sloan Consortium.

Chen, Won S.; Yao \& Adrian Yong T. (2016). An Empirical Evaluation of Critical Factors Influencing Learner Satisfaction in Blended Learning: A Pilot Study. Universal Journal of Educational Research, 2016, 4(7), 1667-1671.

Christie, M. \& Garotte, R. J. (2011) Singapore student teachers' intentions and practices in integrating technology in their teaching. Changing Demands, Changing Directions. Proceedings ascilite Hobart, 234-238.

Devers, Kelly J. \& Frankel, Richard M. (2000). Study design in qualitative research--2: Sampling and data collection strategies. Education for health, 13(2): 263.

Fleming, J., et al. (2017). Factors for successful e-learning: does age matter?. Education+ Training, 59(1), 76-89.

Garner, R. \& Rouse, E. (2016). Social presence-connecting pre-service teachers as learners using a blended learning model. Student Success, 7(1), 25-36.

Garrison, D. R. \& Kanuka, H. (2004). Blended learning: Uncovering its transformative potential in higher education. The internet and higher education, 7(2), 95-105.

Garrison, D. R. \& Vaughan, N. D. (2008) Blended learning in higher education: Framework, principles, and guidelines. John Wiley \& Sons.

Garrote Jurado, R. (2012). Barriers to a wider Implementation of LMS in Higher Education: a Swedish case study, 2006-2011.

Graham, Charles R. (2006). Blended learning systems. The handbook of blended learning, 3-21.

Herreid, C. F. \& Schiller, N. A. (2013). Case studies and the flipped classroom. Journal of College Science Teaching, 42(5), 62-66. 
Hofmann, J. (2006). Why Blended learning hasn't (yet) fulfilled its promises. Handbook of blended learning: Global perspectives, local designs, 27-40.

Holland, Paul M. (2016). Developing a blended learning approach for the effective teaching of electronic circuit analysis. In: Systems, Signals and Image Processing (IWSSIP), 2016 International Conference on. IEEE, p. 1-4.

Kim, J., Kwon, Y., \& Cho, D. (2011). Investigating factors that influence social presence and learning outcomes in distance higher education. Computers \& Education, 57(2), 1512-1520.

Levin, K. A. (2006). Study design III: Cross-sectional studies. Evidence-based dentistry, 7(1), 24-25.

Lin, W-S. \& Wang, Ch-H. (2012). Antecedences to continued intentions of adopting e-learning system in blended learning instruction: A contingency framework based on models of information system success and task-technology fit. Computers \& Education, 58(1), 88-9

Lonn, S. \& Teasley, S. D. (2009). Saving time or innovating practice: Investigating perceptions and uses of Learning Management Systems. Computers \& Education, 53(3), 686-694.

Mann, C. J. (2003). Observational research methods. Research design II: cohort, cross sectional, and casecontrol studies. Emergency medicine journal, 20(1), 54-60.

Mcgee, P. \& Reis, A. (2012). Blended course design: A synthesis of best practices. Journal of Asynchronous Learning Networks, 16(4), 7-22.

Mozelius, P. (2014). Education for All in Sri Lanka: ICT4D Hubs for Region-wide Dissemination of Blended Learning. PhD Thesis. Department of Computer and Systems Sciences, Stockholm University.

Neumeier, P. (2005). A closer look at blended learning — parameters for designing a blended learning environment for language teaching and learning. ReCALL, 17(2), 163-178.

Picciano, A. G. (2009). Blending with purpose: The multimodal model. Journal of asynchronous learning networks, 13(1), 7-18.

QSR International [online]. (2016). "What is NVivo?” [cit. 20161014]. Available from: http://www.qsrinternational.com/what-is-nvivo

Raphael, Ch. \& Mtebe, Joel S. (2016). Instructor support services: An inevitable critical success factor in blended learning in higher education in Tanzania. International Journal of Education and Development using Information and Communication Technology, 12(2), 123.

Shand, K., Glassett Farrelly, S. \& Costa, V. (2016). Principles of course redesign: A model for blended learning. In: Proceedings of Society for Information Technology \& Teacher Education International Conference 2016. p. 378-389.

Slomanson, William R. (2014). Blended learning: A flipped classroom experiment. Journal of Legal Education, 64(1), 93-102.

So, H-J \& Brush, T. A. (2008). Student perceptions of collaborative learning, social presence and satisfaction in a blended learning environment: Relationships and critical factors. Computers \& Education, 51(1), 318-336.

Thai, T. Nt., De Wever, B. \& Valcke, M. (2017). The impact of a flipped classroom design on learning performance in higher education: Looking for the best "blend" of lectures and guiding questions with feedback. Computers \& Education.

Waldrop, M. M. (2014). Massive open online courses, aka MOOCs, transform higher education and science. 
Watson, J. (2008). Blended Learning: The Convergence of Online and Face-to-Face Education. Promising Practices in Online Learning. North American Council for Online Learning. 